\title{
BIODEGRADATION OF TANNERY EFFLUENT AND ITS IMPACT ON SEED GERMINATION OF ORYZA SATIVA
}

\author{
Jenny Sivakumar ${ }^{*}$, Malliga Perumal ${ }^{* *}$ \\ * Cauvery College for Women (Autonomous), Tiruchirappalli, Tamil Nadu, India \\ Bharathidasan University, Tiruchirappalli, Tamil Nadu, India \\ corresponding author: Jenny Sivakumar, e-mail: jsjennysiva@gmail.com
}

\author{
Preliminary note \\ Received: August $15^{\text {th }}, 2019$ \\ Accepted: December $21^{\text {st }}$, 2019 \\ HAE-1919 \\ https://doi.org/10.33765/thate.10.3.2
}

\begin{abstract}
Environmental pollution, especially of water bodies, is one of the major problems and it is increased day by day. The contamination of environment with various toxic metals is a serious threat for ecosystem and human health. Industrial effluents may contain toxic metals, harmful volatile compounds and several organic and inorganic compounds such as chromium, cadmium, mercury, arsenic and lead which are directly or indirectly discharged into the environment without adequate treatment. However, tannery industries are the major source of chromium contamination into the environment. Tanneries are typically characterized as pollution intensive industrial complexes which generate widely varying, high-strength wastewaters. The discharge of these toxic effluents has been a major loss from the ecological, social and economic perspective. There are many conventional physiochemical methods available for the removal of heavy metals from the tannery effluents that are highly expensive and require skilled techniques. However, microbial reduction of toxic chromium to non-toxic chromium by chromium resistance microorganism is the most pragmatic approach that offers an economical as well as eco-friendly process. Hence, this study examines the biodegradation of tannery effluent and its impacts on the germination of Oryza sativa seeds.
\end{abstract}

Keywords: tannery effluent, heavy metals, pollution, biodegradation, seed germination

\section{INTRODUCTION}

Disposal of waste water from industries is one of the major problems and almost all surrounding area is polluted by these industries [1]. Industries discharge a variety of pollutants in their wastewater including heavy metals, resin pellets, organic toxins, oils, nutrient and solids. Many of the tanneries have poor environmental controls and pose a threat to the environment [2]. Discharge of tannery wastewater into water bodies is not safe because it creates harmful effects to aquatic ecosystems and also the people residing in these industries [3]. Most of the industries pollute different water bodies such as lakes, rivers, oceans and ground water [4]. Therefore, these effluents can be properly treated using 
bacterial consortium that can be suitable for irrigation purposes because the physicochemical parameters were found to be relatively high in untreated tannery effluent that severely affect the plant health [5]. Generally, the effects of tannery effluent on germination and growth performance showed that effluent was not fit for irrigation due to higher concentration of organic and inorganic matter and heavy metal contents. The tannery effluent cannot be used for irrigation purposes without proper treatment [6]. Hence, this study aimed to treat tannery effluent by biological methods and to study its impact on seed germination of Oryza sativa.

\section{EXPERIMENTAL}

\section{Sample collection}

The effluent sample was collected from the tannery industry, near Dindugal district, Tamil Nadu, India. The sample was collected in a sterile container and stored in a refrigerator for further studies.

\section{Analysis of physicochemical parameters}

The physicochemical parameters of the tannery effluent such as colour, $\mathrm{pH}$, total solids (TS), total suspended solids (TSS), total dissolved solids (TDS), biological oxygen demand (BOD), chemical oxygen demand (COD), calcium and magnesium were estimated using the standard methods [7].

\section{Bacterial isolation}

The nutrient agar medium was used for the isolation of heavy metals resistant bacteria and the tannery effluent sample directly streaked on nutrient media and incubated at $37{ }^{\circ} \mathrm{C}$ for 24 hours. After the incubation period, the plates were observed for growth on the media and the isolated colonies were selected for the further studies. Microscopic and biochemical tests were applied to this isolates and identified according to Bergey's manual of systematic bacteriology. The genera to which the isolates belong were determined. The selected isolates were stored on the nutrient agar medium at $4{ }^{\circ} \mathrm{C}$ for further studies.

\section{Biodegradation of tannery effluent}

Biodegradation process was done by using selected strains. A loop full of bacterial culture was transferred to test tube containing $10 \mathrm{~mL}$ nutrient broth and incubated at $37{ }^{\circ} \mathrm{C}$ for 24 hours. After incubation, $10 \mathrm{~mL}$ culture was transferred to conical flask containing $100 \mathrm{~mL}$ broth. For biodegradation process, the bacterial culture was inoculated in the sterile and controlled (unsterile) tannery effluent. Then, the tubes were incubated at $37^{\circ} \mathrm{C}$ for 24 hours.

\section{Seed germination study}

In this study, the tannery filtrate was used for Oryza sativa L. seed germination by Whatman filter paper method. 10 paddy seeds were placed on the each Petri dish and incubated at room temperature for seed germination. Radical length, hypocotyl length and germination percentage were measured from first day till $10^{\text {th }}$ day.

\section{RESULTS AND DISCUSSION}

The physicochemical characteristics of tannery effluent were analysed before and after treatment and it was showed in Table 1. The raw effluent was brown in colour and after treatment there was a decrease in $\mathrm{pH}$, TDS, BOD, COD, calcium and magnesium contents. This was mainly due to higher concentration of bacterial biomass in the effluent. The bacterial isolates from the tannery effluent were identified as Enterobacter sp. (Figure 1 and 2) according to Bergey's manual of systemic bacteriology. 
Table 1. Physicochemical properties of tannery effluent before and after treatment

\begin{tabular}{|c|c|c|}
\hline $\begin{array}{c}\text { Parameters } \\
(\mathrm{mg} / \mathrm{L})\end{array}$ & $\begin{array}{c}\text { Untreated } \\
\text { effluent }\end{array}$ & $\begin{array}{c}\text { Treated } \\
\text { effluent }\end{array}$ \\
\hline Colour & Brown & $\begin{array}{c}\text { Light } \\
\text { yellow }\end{array}$ \\
\hline Temperature & $34^{\circ} \mathrm{C}$ & $36^{\circ} \mathrm{C}$ \\
\hline $\mathrm{pH}$ & 8.5 & 7.0 \\
\hline $\mathrm{TDS}$ & 37.95 & 36.9 \\
\hline $\mathrm{TSS}$ & 1.28 & 1.15 \\
\hline BOD & 2000 & 250 \\
\hline COD & 1100 & 150 \\
\hline Calcium & 250 & 200 \\
\hline Magnesium & 316.55 & 255.67 \\
\hline
\end{tabular}

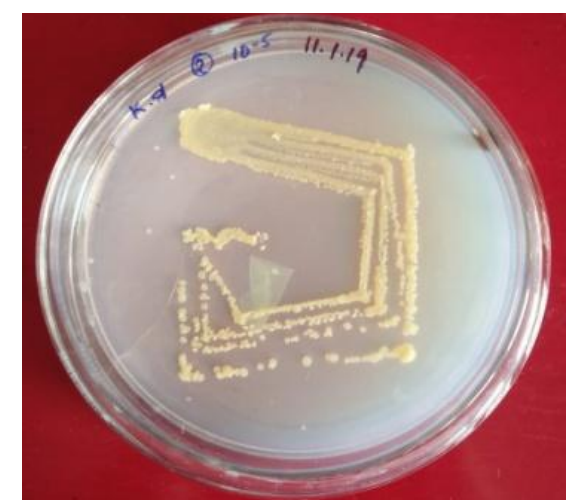

Figure 1. Enterobacter sp.

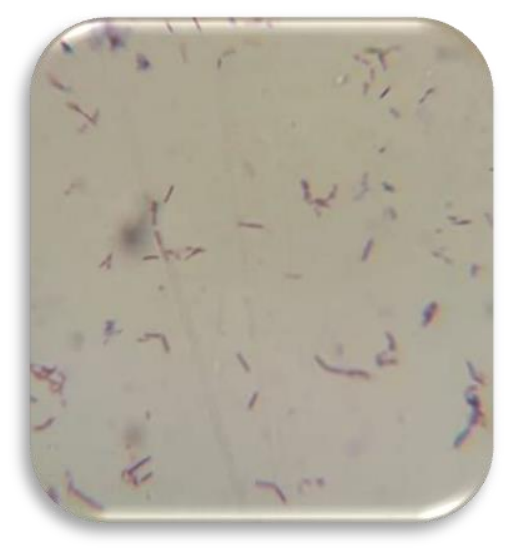

Figure 2. Microscopic view of Enterobacter sp. $(40 X)$

After 72 hours, the physicochemical properties were found decreased in the effluent [5]. The industrial sample colour changed from blackish to light brown after degradation using native E. coli and in non-native Bacillus sp. [8]. The physiochemical parameters were found to be reduced in all the treatments but significant reduction was observed only with the combined treatment [9]. The reduction of biological oxygen demand in tannery effluents was reduced after inoculation of Rhodopseudomonas blastica. Aspergillus sp. was used at various concentrations to treat the effluent [10]. Reduction of COD in tannery effluents was also noticed after inoculation of Enterococcus casseliflavous [11]. The COD level was reduced by Botryosphaeria rhodina after five days under agitation [12].

Seed germination was done by using sterile and unsterile treated filtrate and the parameters were measured (Figure 3). The treated tannery effluent containing Enterobacter sp. was used to promote plant growth and suppress the plant disease. The percentage of seed germination, radical length, and hypocotyl length in tannery with bacteria is higher than other treatments (Figure 4) on $10^{\text {th }}$ day.

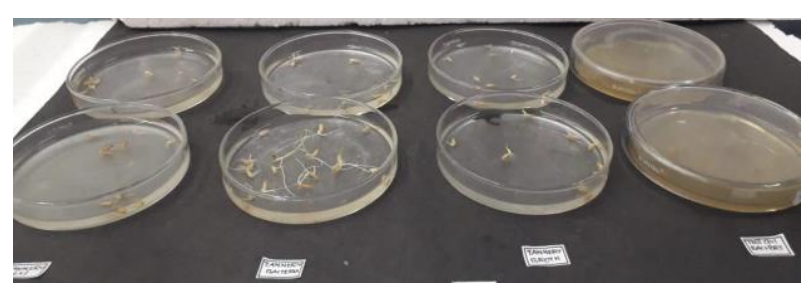

Figure 3. Seed germination using sterile and unsterile treated tannery effluent on $10^{\text {th }}$ day
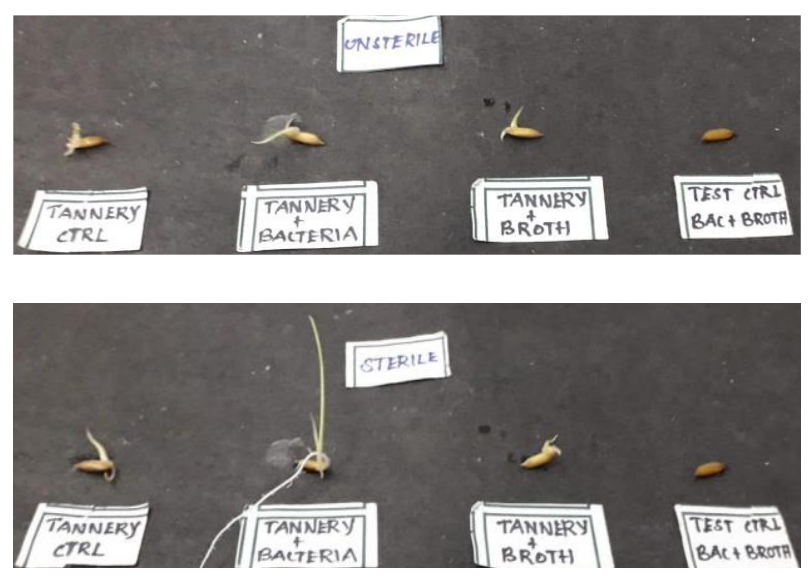

Figure 4. Analysis of morphological parameters on Oryza sativa L.

The tannery effluent showed a significant effect on seed germination and morphological parameters [13]. The percentage of seed germination, seedling growth and fresh weight of green gram were increased with different 
concentration of tannery effluent [14]. The application of treated tannery effluent promoted the seed germination of Vigna radiata $\mathrm{L}$. when compared to chemical treatment [15].

\section{CONCLUSION}

The physicochemical parameters of tannery effluent were reduced after treatment with Enterobacter sp. The results indicated that bacterial treatment method is a feasible technique for bioremediation of tannery effluent. Therefore, it was found that the remediation using Enterobacter sp. provides an effective and environmentally acceptable option for wastewater treatment. This study concluded that the Enterobacter sp. have the capacity to degrade the tannery effluent and promote the seed germination of Oryza sativa L.

\section{REFERENCES}

[1] P. Thamizhiniyan, P.V. Sivakumar, M. Lenin, M. Sivaraman, Sugar Mill Effluent Toxicity in Crop Plants, Journal of Phytology 1(2009) 2, 68-74.

[2] M.R. Azom, K. Mahmud, S.M. Yahya, A. Sontu, S.B. Himon, Environmental Impact Assessment of Tanneries: A Case Study of Hazaribag in Bangladesh, International Journal of Environmental Science and Development 3(2012) 2, 152-156.

[3] S. Parveen, R. Bharose, D. Singh, Assessment of Physico-Chemical Properties of Tannery Waste Water and Its Impact on Fresh Water Quality, International Journal of Current Microbiology and Applied Sciences 6(2017) 4, 1879-1887.

[4] S.A. Begum, M.J. Alam, S.S. Rahman, M.M. Rahman, Effect of industrial effluents on the germination and seedling growth of three leafy vegetables, Bangladesh Journal of
Scientific and Industrial Research 45(2010) 2, 101-104.

[5] K. Mythili, B. Karthikeyan, Bioremediation of tannery effluent and its impact on seed germination (black gram and sunflower), Current Botany 2(2011) 8, 40-45.

[6] M. Hailu, M. Muthuswamy, Y. Petros, Effects of Tannery Effluent on Seed Germination and Growth Performance of Selected Varieties of Maize (Zea mays L.), International Journal of Scientific and Research Publications 9(2019) 3, 242-251.

[7] APHA, Standard methods for the examination of water and wastewater, $18^{\text {th }}$ Edition, American public health association, American water works association, Water Environmental federation, Washington DC, 1998.

[8] C.M. Noorjahan, D. Sharief, N. Dawood, Characterization of diary effluent, Journal of Industrial Pollution Control 20(2004) 1, 131-136.

[9] L. Karuppaiah, R. Suntharam, M. Perumal, Bioremediaton of Tannery Effluent Using Lyngbya Sp. with Coir Pith, International Journal of Science and Research 4(2015) 1, 2736-2743.

[10] K. Duangporn, T. Salwa, U. Kamontam, The potential use of an oxygenic Phototrophic bacteria for treating Latex rubber sheet waste water, Electronic Journal of Biotechnology 8(2005) 3, 314-323.

[11] P. Saranraj, D. Shella, D. Reetha, K. Mythili, Bioadsorption of Chromium Resistant Enterococcus casseliflavus isolated from tannery effluent, Journal of Ecobiotechnology 2(2010) 7, 17-22.

[12] M.C. Hasegawa, A.M. Barbosa, K. Takashima, Biotreatment of industrial tannery waste water using Botryosphaeria rhodina, Journal of the Serbian Chemical Society 76(2011) 3, 439-446.

[13] A. Asfaw, M. Sime, F. Itanna, Determining the Effect of Tannery Effluent on Seeds Germination of Some Vegetables in Ejersa Area of East Shoa, Ethiopia, International Journal of 
Scientific and Research Publications 2(2012) 12, 1-10.

[14] V.K. Singh, Z. Ali, A. Raj, Study of impact of tannery effluent on river water quality using Vigna radiata L. bioassay, Research Journal of Chemistry and Environment 18(2014) 1, 62-65.

[15] S. Kalaibharathi, R. Sowmya, P. Malliga, Germination Study On Vigna radiata $\mathrm{L}$. Seeds Using Tannery Effluent Treated with Coir Pith and Nava Rasa Karaisal, Chemical Science Review Letter 8(2019) 30, 210-215.

\section{Acknowledgements}

Authors are grateful to Cauvery College for Women (Autonomous), Tiruchirappalli, Tamil Nadu for the facility and completion of this work. 